\title{
Article
}

\section{The Upcoming ${ }^{6} \mathrm{Li}$ Isotope Requirements Might Be Supplied by a Microalgal Enrichment Process}

\author{
Héctor M. Díaz-Alejo ${ }^{1}{ }^{10}$, Victoria López-Rodas ${ }^{1}$, Camino García-Balboa ${ }^{1}$, Francisco Tarín ${ }^{2}$, Ana I. Barrado ${ }^{3}$, \\ Estefanía Conde ${ }^{3}$ and Eduardo Costas ${ }^{1, *}$ \\ 1 School of Veterinary Medicine, Complutense University of Madrid, Av. Puerta de Hierro s/n, \\ 28040 Madrid, Spain; hectormd@ucm.es (H.M.D.-A.); vlrodas@ucm.es (V.L.-R.); camino@ucm.es (C.G.-B.) \\ 2 ENUSA Advanced Industries S.A., S.M.E., Santiago Rusiñol 12, 28040 Madrid, Spain; ftg@enusa.es \\ 3 Spanish Research Centre for Energy, Environment and Technology (CIEMAT), Av. Complutense 40, \\ 28040 Madrid, Spain; anaisabel.barrado@ciemat.es (A.I.B.); estefania.conde@ciemat.es (E.C.) \\ * Correspondence: ecostas@ucm.es
}

check for updates

Citation: Díaz-Alejo, H.M.;

López-Rodas, V.; García-Balboa, C.;

Tarín, F.; Barrado, A.I.; Conde, E.;

Costas, E. The Upcoming ${ }^{6} \mathrm{Li}$ Isotope

Requirements Might Be Supplied by a

Microalgal Enrichment Process.

Microorganisms 2021, 9, 1753.

https: / / doi.org/10.3390/

microorganisms 9081753

Received: 20 July 2021

Accepted: 13 August 2021

Published: 17 August 2021

Publisher's Note: MDPI stays neutral with regard to jurisdictional claims in published maps and institutional affiliations.

Copyright: (c) 2021 by the authors. Licensee MDPI, Basel, Switzerland. This article is an open access article distributed under the terms and conditions of the Creative Commons Attribution (CC BY) license (https:// creativecommons.org/licenses/by/ $4.0 /)$.

\begin{abstract}
Lithium isotopes are essential for nuclear energy, but new enrichment methods are required. In this study, we considered biotechnology as a possibility. We assessed the Li fractionation capabilities of three Chlorophyte strains: Chlamydomonas reinhardtii, Tetraselmis mediterranea, and a freshwater Chlorophyte, Desmodesmus sp. These species were cultured in Li containing media and were analysed just after inoculation and after 3, 12, and 27 days. Li mass was determined using a Inductively Coupled Plasma Mass Spectrometer, and the isotope compositions were measured on a Thermo Element XR Inductively Coupled Plasma Mass Spectrometer. The maximum Li capture was observed at day 27 with C. reinhardtii $(31.66 \mu \mathrm{g} / \mathrm{g})$. Desmodesmus sp. reached the greatest $\mathrm{Li}$ fractionation, $\left(\delta^{6}=85.4 \%\right.$ ). All strains fractionated preferentially towards ${ }^{6} \mathrm{Li}$. More studies are required to find fitter species and to establish the optimal conditions for Li capture and fractionation. Nevertheless, this is the first step for a microalgal nuclear biotechnology.
\end{abstract}

Keywords: lithium; fractionation; microalgae; biotechnology; stable isotopes

\section{Introduction}

Future prospects for energy demand make it necessary to provide humans with an important ratio of $\mathrm{KJ} /$ (person $\times$ day) to satisfy the daily consumption all over the world. In 2019, energy consumption was over 160,000 TWh [1]. Additionally, the energy requirements must be supplied without posing a threat to human life and under environmentally sustainable criteria.

In that respect, fusion energy has become one of the most promising future sources of energy [2]. A project as relevant as ITER implies that researchers and engineers from different countries are approaching this challenge, aiming to obtain positive net energy from fusion reactions. To accomplish this, two reactants are required: two heavy hydrogen isotopes—deuterium, and tritium—as shown in Equation (1):

$$
\mathrm{D}+\mathrm{T} \rightarrow 4 \mathrm{He}+\mathrm{n}+17.6 \mathrm{MeV}
$$

Deuterium may be obtained from seawater, where it is present at a concentration of $33 \mathrm{~g} / \mathrm{m}^{3}$ [3]. Tritium is an isotope that is not abundant in nature but can be obtained from ${ }^{6} \mathrm{Li}$ as in the process shown in Equation (2).

$$
{ }^{6} \mathrm{Li}+\text { neutron } \rightarrow{ }^{3} \mathrm{H} \text { (Tritium) }+{ }^{4} \mathrm{He}
$$

Thus, lithium is a key element in the search for a green, efficient energy. From an isotopic point of view, lithium consists of two isotopes whose natural relative abundance is $7.59 \%$ for ${ }^{6} \mathrm{Li}$ and $92.41 \%$ for ${ }^{7} \mathrm{Li}$ [4]. Both lithium isotopes are strategic for the nuclear 
technology since ${ }^{7} \mathrm{Li}$ is used to control the chemistry of the primary circuit in pressurized water nuclear reactors, while ${ }^{6} \mathrm{Li}$ is used as neutron shield and detector in neutron beam facilities. Additionally, the advancement of nuclear fusion projects will create a high demand for this isotope to regenerate tritium. For this purpose, the enrichment needed in the ${ }^{6} \mathrm{Li}$ isotope is around 30 to $90 \%$, far above what is found naturally $(7.59 \%)$ [5-7].

Since vast amounts of ${ }^{6} \mathrm{Li}$ are required for fusion projects, the resultant ${ }^{7} \mathrm{Li}$ is perfectly usable for battery production and nuclear fission reactors as an acidic control in pressurized water-moderated reactors (PWR) or as a coolant in GEN IV molten salt reactors since no tritium generation is desired in these systems [5]. The electric transportation sector is also interested in ${ }^{7} \mathrm{Li}$ since it confers greater electromotive force, recharging speed, and useful life to batteries [8]. These synergistic demands for each of the lithium isotopes justify and reinforce the interest in developing efficient and scalable technologies of isotopic separation technologies [8].

To achieve fractionation, different methods based on physicochemical approaches have been developed, such as chemical, electrochemical, displacement chromatography, and laser-based methods [9]. Most of them have been proven at a laboratory scale and are very costly in terms of scaling and energy consumption. To our knowledge, however, Li fractionation has so far only been used industrially with the amalgam method [10], a chemical exchange process that uses high quantities of mercury that must be disposed of, posing an environmental and health risk [11,12].

Furthermore, nowadays, the majority of ${ }^{6} \mathrm{Li}$ comes from a limited source and is produced in Oak Ridge [9], so envisioning the proximal future demand for ${ }^{6} \mathrm{Li}$, the implementation of plants to obtain huge amounts of enrichment must be achieved.

For these new plants to be more sustainable, green and more efficient technologies would be required [9]. To achieve this, nature could provide us with powerful knowledge since isotopes may be naturally fractionated during different biogeochemical processes.

Excluding hydrogen, the two isotopes of $\mathrm{Li},{ }^{6} \mathrm{Li}$, and ${ }^{7} \mathrm{Li}$, have the biggest relative mass difference ( $16.6 \%)$ of any isotope pair, providing itself an advantage towards fractionation. Lithium fractionation in nature varies in geological and natural samples, with values for $\delta^{7}$ $\left(\left[\left(R_{\text {measured }}-\mathrm{R}_{\text {reference }}\right) /\left(\mathrm{R}_{\text {reference }}\right)\right] \times 1000\right)$ that range between around $30 \%$ in seawater to negative values in weathered soils and in soil solutions [13]. Taylor and Urey (1938) found an isotopic fractionation of $250 \%$ when Li-solutions percolate through a zeolite [14]. During weathering, fractionation occurs due to the primary dissolution of silicate rocks like granites and the formation of secondary minerals [15-18]. This can lead to producing large isotopic fractionation in terrestrial systems, with the variation of ${ }^{7} \mathrm{Li} /{ }^{6} \mathrm{Li}$ ranging from -20 to $+40 \%$ o $[19,20]$ up to $80 \%$ o [21].

Another possible fractionation mechanism is through biological systems. In mammals, including humans, Li isotopic fractionation process has been widely spotted [22-24]. The isotope relevance escalates to the point that they even exhibit different toxicity and lethality for ${ }^{6} \mathrm{Li}$ and ${ }^{7} \mathrm{Li}[25,26]$. To show isotopic fractionation, a Li-organism interaction must exist. Many of the effects that Li can cause in living organisms may be explained by its competition with sodium, potassium, calcium, and magnesium due to its similar charge and size [27-30]. Because of its ubiquity in our environment, the ingestion of lithium in at least trace amounts is unavoidable [27]. Some plants have increased growth rates in the presence of lithium, but in other cases, lithium can also be toxic at high concentrations, so an optimal Li concentration for some organisms is likely to exist (as reviewed by Shahzad et al. [31]). Experiments conducted with bacteria such as E. coli or Salmonella typhimurium showed that $\mathrm{Li}^{+}$ions as well as $\mathrm{Na}^{+}$ions can be co-transported with trimethylglycine [32]. Additionally, $\mathrm{Li}^{+}$could have a stimulating effect on proline transport in E. coli [33]. As such, the relationship between lithium and living organisms is, even if not essential, existent.

Among the living beings that can potentially be used in biotechnological processes, microorganisms have a predominant role. The fractionation ability of microorganisms has been widely demonstrated [34-40]. Lithium, albeit not widely studied, is no exception, as one study testing different bacteria found $\mathrm{Li}$ isotopic fractionation with different rates 
between species [41]. However, to our knowledge, no further studies on microbiological fractionation were found to be related to this element.

Microalgae have great acceptance and usefulness for biotechnological applications due to their properties: their ability to adapt to extreme environments [42-49], their ubiquity, their relatively easy culture conditions, and their ability capture $\mathrm{CO}_{2}$ while growing, helping to alleviate ongoing climate change (reviewed by Kumar et al. [50]). Additionally, related to our subject, they are well suited for metal uptake processes, either as dead biomass or while using them alive [51-57]. Previous studies allowed us to prove the fractionation of ${ }^{235} \mathrm{U}$ and ${ }^{238} \mathrm{U}$ employing a microalga isolated from a polluted extreme uranium mining environment with a maximum $\delta^{235}$ of $540 \%$ [58]. Additionally, some studies revealed the possible use of microalgae to recover lithium from a solution $[54,59]$, but no further studies deepening this field have been found. Considering the valuable and promising properties of microalgae in terms of biotechnology, this study aimed to determine whether these microorganisms can fractionate lithium isotopes in laboratory conditions.

\section{Materials and Methods}

\subsection{Microalgae Strains and Growth Conditions}

A total of three Chlorophyta microalgae strains were used, two freshwater wildtype strains, an unidentified Chlorophyta (CAFE strain), and Chlamydomonas reinhardtii Dangerad (ChlA strain) and one marine wildtype strain, Tetraselmis mediterranea (Lucksch) R.E. Norris, Hori \& Chihara (strain TmS1), was also used. The three strains were obtained from the Universidad Complutense de Madrid microalgae culture collection. The CAFE strain was isolated from the Entreuka Guelta (SE Mauritania); the ChlA strain was isolated from Doñana National Park (SW, Spain), and the TmS1 strain was isolated from waters off the eastern coast of Sardinia (Italy). The ChlA and TmS1 strains were selected as they belong to Chlorophyte genera used as model systems for freshwater and marine eukaryotic microalgae $[60,61]$. The CAFE strain was identified in this study, described in CAFE strain identification as Desmodesmus sp. and was chosen as a random strain to increase basic knowledge in the field.

Under laboratory conditions, strains were grown in $100 \mathrm{~mL}$ cell culture flasks (Greiner; Bio-One Inc., Longwood, NJ, USA) with 20 mL of BG-11 medium (Sigma-Aldrich Chemie, Taufkirchen, Germany) for the freshwater algae, and filtered seawater enriched with Guillard's F/ 2 broth (Sigma-Aldrich Chemie, Taufkirchen, Germany) was used for the TmS1 strain. Culture media was prepared according to the manufacturers' instructions. To keep a mid-log-exponential growth, the strains were transferred to a new culture flask within 20 days of its prior transfer. Cultures were maintained at $22{ }^{\circ} \mathrm{C}$ with continuous illumination at $80 \mu \mathrm{m} / \mathrm{m}^{2} \cdot \mathrm{s}^{1}$ within the wavelength of $400-700 \mathrm{~nm}$. For the experiments, $\mathrm{LiCl}$ (Sigma-Aldrich, BioXtra, $\geq 99.0 \%$ purity) was dissolved in the freshwater and marine media.

\subsection{CAFE Strain Identification}

An isolated CAFE culture was sent to Secugen S.L. (Madrid, Spain) for DNA extraction, amplification of 18S RNA and ITS genes, and sequencing from both ends. These genes have been successfully used in previous Chlorophyte identifications.

The DNA for the PCR was extracted by centrifuging $100 \mu \mathrm{L}$ of liquid culture and inserting the pellet in an FTA ${ }^{\circledR}$ Card. Forward and reverse gene sequences were amplified using the primers indicated in Table 1. 
Table 1. Target genes and primers used for the 18S [62] and ITS [63] regions.

\begin{tabular}{ccc}
\hline Gene & Primer Name & Primer Sequence \\
\hline \multirow{2}{*}{$18 \mathrm{~S}$} & 18SF1 & GGT TGA TYC TGC CAG TAG \\
& 18 SR1 & GMW ACC TTG TTA CGA CTT \\
\hline \multirow{2}{*}{ ITS } & ITSu1 & GGA AGK ARA AGT CGT AAC AAG G \\
& ITSu4 & RGT TTC TTT TCC TCC GCT TA \\
\hline
\end{tabular}

The $18 \mathrm{~S}$ gene PCR was conducted under the following conditions: $95{ }^{\circ} \mathrm{C} 15 \mathrm{~min}+$ $\left(95{ }^{\circ} \mathrm{C} 30 \mathrm{~s}+55{ }^{\circ} \mathrm{C} 40 \mathrm{~s}+72{ }^{\circ} \mathrm{C} 2 \mathrm{~min}\right) \times 35+72{ }^{\circ} \mathrm{C} 10 \mathrm{~min}$. For the ITS region, the following protocol was applied: $95{ }^{\circ} \mathrm{C} 15 \mathrm{~min}+\left(95^{\circ} \mathrm{C} 30 \mathrm{~s}+53{ }^{\circ} \mathrm{C} 40 \mathrm{~s}+72{ }^{\circ} \mathrm{C} 1 \mathrm{~min}\right) \times$ $35+72{ }^{\circ} \mathrm{C} 10 \mathrm{~min}$. For both protocols, the TaqGold (Applied Biosystems ${ }^{\mathrm{TM}}$, Thermo Fisher Scientific Inc., Waltham, MA, USA) polymerase was used. PCR products were checked by visualization in agarose gel. DNA sequencing from both ends was conducted using the reactant BigDye 3.1 followed by capillary electrophoresis in an automatic sequencer ABI 3730xl. The obtained sequences were assembled and edited using the BioEdit software. A consensus sequence conducted for 18S and the ITS genes was compared using the Basic Local Alignment Search Tool (BLAST), a National Center for Biotechnology Information (NCBI) database.

The final strain identification was based on the 18S ribosomal RNA gene, internal transcribed spacer (ITS), and by morphological comparison with the AlgaeBase (www. algaebase.org) (accessed date: 10 September 2020) [64-66]. Internal transcribed spacer (ITS) and $18 \mathrm{~S}$ ribosomal RNA genes obtained from the CAFE isolate were assembled, edited, and deposited in GenBank.

\subsection{Lithium Uptake and Isotope Fractionation Trials}

The lithium uptake and Li-isotope fractionation behaviour of the three Chlorophytes was conducted in a bioassay. Cultures were prepared in flasks containing $20 \mathrm{~mL}$ of the respective culture media. Lithium reached a concentration of $4.2 \mathrm{mg} / \mathrm{L}$ in BG-11 culture medium and a concentration of $2.5 \mathrm{mg} / \mathrm{L}$ in F2 medium. Additionally, one control without cells for each medium was established. The initial cellular inoculum was of approximately $8 \times 10^{5}$ cells for TmS1 and CAFE and approximately $7 \times 10^{5}$ cells for ChlA. Cell densities were estimated by counting with counting chambers (Fast Read; Biosigma, Venice, Italy) under a microscope Zeiss 4730 12-9902 (Zeiss, Oberkochen, Germany).

The bioassay was conducted in aerobic conditions at $22{ }^{\circ} \mathrm{C}$ and $\mathrm{pH} 8.11$ for $\mathrm{F} / 2$ and at 5.82 for BG/11 cultures. A total of four cultures were prepared for each strain, and each culture was to be centrifuged at a specific time: immediately after inoculation (considered 0 days) or after 3,12, or 27 days. The whole volume of each culture was centrifuged at $4000 \mathrm{rpm}$ for $15 \mathrm{~min}$. The pellets were frozen until analysis. Solutions of BG-11 and F/2 enriched with lithium were also analysed during the experimental times to serve as chemical control. Isotopic analysis and total Li quantifications were performed at CIEMAT (Spanish Research Centre for Energy, Environment, and Technology). Li isotopic relationship results were obtained by averaging the data obtained from two pseudo-replicate analyses of each sample.

\subsection{Analytical Procedure}

\subsubsection{Sample Dissolution and Lithium Separation}

Algal pellets $(\mathrm{mg})$ were subjected to acid digestion with $5 \mathrm{~mL}$ of a $\mathrm{HNO}_{3}-\mathrm{H}_{2} \mathrm{O}_{2}$ mixture $(4: 1 \mathrm{v} / \mathrm{v})$ in Teflon beakers and gentle heating on a hotplate until a transparent solution was achieved. Sample solutions were then evaporated until almost dry, and the residues were dissolved in $3 \mathrm{M} \mathrm{HNO}_{3}$. One millilitre of this solution was brought to a final volume of $10 \mathrm{~mL}$ with MilliQ water to quantify the Li by quadrupole-based ICP-MS (Q-ICP-MS) using the external calibration and internal standard method. The drying operation was repeated, 
with the remaining volume and the residue being dissolved in $2 \mathrm{~mL}$ of $\mathrm{HCl} 0.2 \mathrm{M}$, which was used for lithium isotopic analysis after lithium purification through chromatography.

\subsubsection{Chromatography}

The separation of lithium from other matrices is crucial for precise Li isotope measurement. This step was conducted in a single-step chromatographic separation using $1.5 \mathrm{~cm}$ polypropylene columns (Bio-Rad Laboratories, Inc., Hercules, CA, USA) packed with cation-exchange resin, Dowex 50W-X8 (50-100 mesh size).

Prior to sample loading, the columns were pre-washed with $20 \mathrm{~mL}$ of $6 \mathrm{M} \mathrm{HCl}$ and were then conditioned with $10 \mathrm{~mL}$ of $0.2 \mathrm{M} \mathrm{HCl}$. Samples in $0.2 \mathrm{M} \mathrm{HCl}$ medium were loaded and were subsequently eluted with $40 \mathrm{~mL}$ of $0.2 \mathrm{M} \mathrm{HCl}$, with the eluate volume ranging from $20 \mathrm{~mL}$ to $32 \mathrm{~mL}$ of the corresponding to lithium fraction. These $12 \mathrm{~mL}$ were collected and were gently evaporated until dry, after which the residue was dissolved in $5 \mathrm{~mL}$ of $2 \% \mathrm{HNO}_{3}(v / v)$.

The lithium solution of each sample was quantified, and its concentration was adjusted by dilution in $2 \% \mathrm{HNO}_{3}$ to an approximate concentration of $1 \mathrm{ppb}$ before isotopic mass spectrometry analysis.

\subsubsection{Mass Spectrometry}

The lithium concentration in samples was determined by Inductively Coupled Plasma Mass Spectrometry (ICP-MS) using a quadrupole instrument equipped with a collision cell (iCAP Q, Thermo Fisher Scientific Inc., Waltham, MA, USA) and by applying the external calibration quantification method and internal standardization. The standard calibration solutions were prepared daily by dilution from a $1000 \mathrm{mg} / \mathrm{L} \mathrm{Li} \mathrm{stock} \mathrm{solution.} \mathrm{According} \mathrm{to}$ the concentration obtained in each sample, these were diluted to a Li content of $1-2 \mathrm{ng} / \mathrm{mL}$.

Isotope compositions were measured on an Element 2 ICP-MS (Thermo Fisher Scientific). Tuning parameters are adjusted before the analyses to maximize instrument sensitivity and stability.

The ${ }^{6} \mathrm{Li} /{ }^{7} \mathrm{Li}$ ratio was measured using a sample-standard bracketing method, where a blank and a certified isotopic standard (IRMM-016, Joint Research Centre European Commission) were measured before and after each sample to correct for the instrumental drift and mass bias. The isotope standard was prepared by matching its concentration with that of the sample, that is, $1 \mu \mathrm{g} / \mathrm{L}$, because an uneven concentration between the sample and the bracketing standards affects the accuracy of the Li isotope analysis. Additionally, blanks were systematically determined and were negligible. The uncertainty associated with the measurement of all ${ }^{6} \mathrm{Li} /{ }^{7} \mathrm{Li}$ isotopic ratios was less than their variation between samples.

\section{Results}

\subsection{CAFE Strain Identification}

The CAFE strain was identified as belonging to the genus Desmodesmus. The identification was based both on the ITS and 18S RNA gene sequences, and on morphological comparison with the AlgaeBase (algaebase.org) (accessed date: 10 September 2020).

Under the BLAST search, both the Desmodesmus and Acutodesmus genera showed an identity over $99 \%$ with the sequenced regions. The final classification of CAFE as Desmodesmus and not Acutodesmus was determined by morphological comparison with the AlgaeBase. Species-level identification was not reached. The obtained sequences were uploaded to GenBank with the accession numbers MT462646 for the ITS region and with the number MW185780 for the small subunit ribosomal RNA gene.

\subsection{Lithium Uptake}

Lithium concentrations in the culture media were analysed, showing $4.2 \mathrm{mg} / \mathrm{L}$ of $\mathrm{Li}$ in $\mathrm{BG}-11+\mathrm{Li}$ and $2.5 \mathrm{mg} / \mathrm{L}$ in $\mathrm{F} 2+\mathrm{Li}$.

The measure of the Li concentration in the assay confirms that the three microalgae that were tested were apt for lithium uptake (Table 2). 
Table 2. Li-mass quantification in each experimental pellet.

\begin{tabular}{ccccc}
\hline Strain & Day & Pellet Mass $(\mathbf{g})$ & $\begin{array}{c}\text { Li Mass in the Pellet } \\
(\mathbf{n g})\end{array}$ & $\begin{array}{c}\text { Li Mass/Biomass } \\
(\boldsymbol{\mu g} / \mathbf{g})\end{array}$ \\
\hline TmS1 & 0 & 0.1273 & 887 & 6.96 \\
TmS1 & 3 & 0.2861 & 1946 & 6.8 \\
TmS1 & 12 & 0.1542 & 1113 & 7.21 \\
TmS1 & 27 & 0.4174 & 3447 & 8.26 \\
\hline CAFE & 0 & 0.0971 & 850 & 8.76 \\
CAFE & 3 & 0.1888 & 1265 & 6.7 \\
CAFE & 12 & 0.2261 & 1512 & 6.69 \\
CAFE & 27 & 0.5786 & 4597 & 7.94 \\
\hline ChlA & 0 & 0.1214 & 885 & 7.29 \\
ChlA & 3 & 0.1432 & 784 & 5.48 \\
ChlA & 12 & 0.3876 & 1641 & 4.23 \\
ChlA & 27 & 0.1926 & 6098 & 31.66 \\
\hline
\end{tabular}

\subsection{Isotope Fractionation Trials}

The enrichment factor $\delta^{6}$ was calculated according to Equation (3), considering $\mathrm{R}_{\text {reference }}$ as the isotopic ratio measured in each specific control media. The calculated enrichment factor for each alga is detailed in Table 3.

$$
\delta=\left[\left(\mathrm{R}_{\text {measured }}-\mathrm{R}_{\text {reference }}\right) /\left(\mathrm{R}_{\text {reference }}\right)\right] \times 1000
$$

Table 3. ${ }^{6} \mathrm{Li}$ relative abundance and enrichment factor $\left(\delta^{6}\right)$ in the experimental cultures.

\begin{tabular}{ccccc}
\hline & \multicolumn{4}{c}{${ }^{{ }^{6} \mathbf{L i} /{ }^{7} \mathbf{L i} \text { Relative Abundance }}$} \\
\hline \multirow{2}{*}{ Strain } & Time (Days) & $\begin{array}{c}\text { Pellet } \\
( \pm \text { Uncertainty) }\end{array}$ & $\begin{array}{c}\text { Medium } \\
( \pm \text { Uncertainty) }\end{array}$ & $\boldsymbol{\delta}^{\mathbf{6}}$ \\
\hline \multirow{3}{*}{ TmS1 } & 0 & $0.08227 \pm 0.00063$ & $0.08239 \pm 0.00098$ & -1.45 \\
& 3 & $0.08247 \pm 0.00027$ & $0.08201 \pm 0.00061$ & 5.58 \\
& 12 & $0.08269 \pm 0.00065$ & $0.08229 \pm 0.00036$ & 4.80 \\
& 27 & $0.08276 \pm 0.00031$ & $0.08207 \pm 0.00010$ & 8.35 \\
\hline \multirow{3}{*}{ CAFE } & 0 & $0.0897 \pm 0.00068$ & $008264 \pm 0.00049$ & 85.39 \\
& 3 & $0.08303 \pm 0.00085$ & $0.08218 \pm 0.00018$ & 10.39 \\
& 12 & $0.08447 \pm 0.00096$ & $0.08232 \pm 0.00071$ & 26.12 \\
ChlA & 27 & $0.08556 \pm 0.00087$ & $0.08193 \pm 0.00048$ & 44.32 \\
& 0 & $0.0826 \pm 0.00074$ & $0.08264 \pm 0.00049$ & -0.44 \\
& 3 & $0.08313 \pm 0.00092$ & $0.08218 \pm 0.00018$ & 11.54 \\
& 12 & $0.08214 \pm 0.00070$ & $0.08232 \pm 0.00071$ & -2.19 \\
& 27 & $0.08508 \pm 0.00057$ & $0.08193 \pm 0.00048$ & 38.40 \\
\hline
\end{tabular}

\section{Discussion}

\subsection{Lithium Capture}

The three strains captured the most in the culture at day 27, but huge differences were found among strains and, arguably, the maximum Li capture was not reached during the period in question. ChlA showed the greatest capture followed by CAFE. According to Li mass relative to wet biomass, TmS1 and CAFE showed a similar uptake without great differences between them. ChlA again proved to be the most effective in incorporating lithium from solution, with a sharp change from day 12 to 27 . For this strain, even if no great biomass increase occurred between days 3 and 27, the total Li mass incremented almost eight-fold. According to our results, the optimal moment for biomass recovery would be at day 27 . However, further studies need to be conducted to determine on which day the maximum uptake is achieved. 
Previous studies conducted with Chlorophytes demonstrated that microalgae can be a potent tool for $\mathrm{Li}$ removal from Li polluted waters [59] or from wastewater where $\mathrm{Li}$ and $\mathrm{Rb}$ are both present [54]. El Naggar et al. [59] evaluated the conditions that yielded the maximum Li capture using the Chlorophyte Oocystis solitaria, considering $\mathrm{pH}$, lithium concentration, and temperature the most influential factors. A maximum of $99.95 \% \mathrm{Li}$ removal was achieved in that assay. Presumably, the maximal uptake conditions would highly depend on the microorganisms used, as each strain has its peculiarities. In our assay, the experimental environment was the same as the conditions in which the culture collection was maintained, thus not causing stress.

Lithium uptake was observed in the three strains within minutes from inoculation, but differences existed. On days 3 and 12, a slight Li-content decline was detected in the CAFE strain, while ChlA depletion was stronger. TmS1 did not show evidence of Li loss. During the last days of the trial, a slight increase in Li capture was observed in CAFE, but it was not enough to restore the initial levels (Figure 1). ChlA took up a total of $6.098 \mu \mathrm{g}$, which represents $31.66 \mathrm{ng} / \mathrm{g}$ of lithium in wet biomass. That amounts to around four times more lithium than the maximum taken up in the case of CAFE or TmS1.

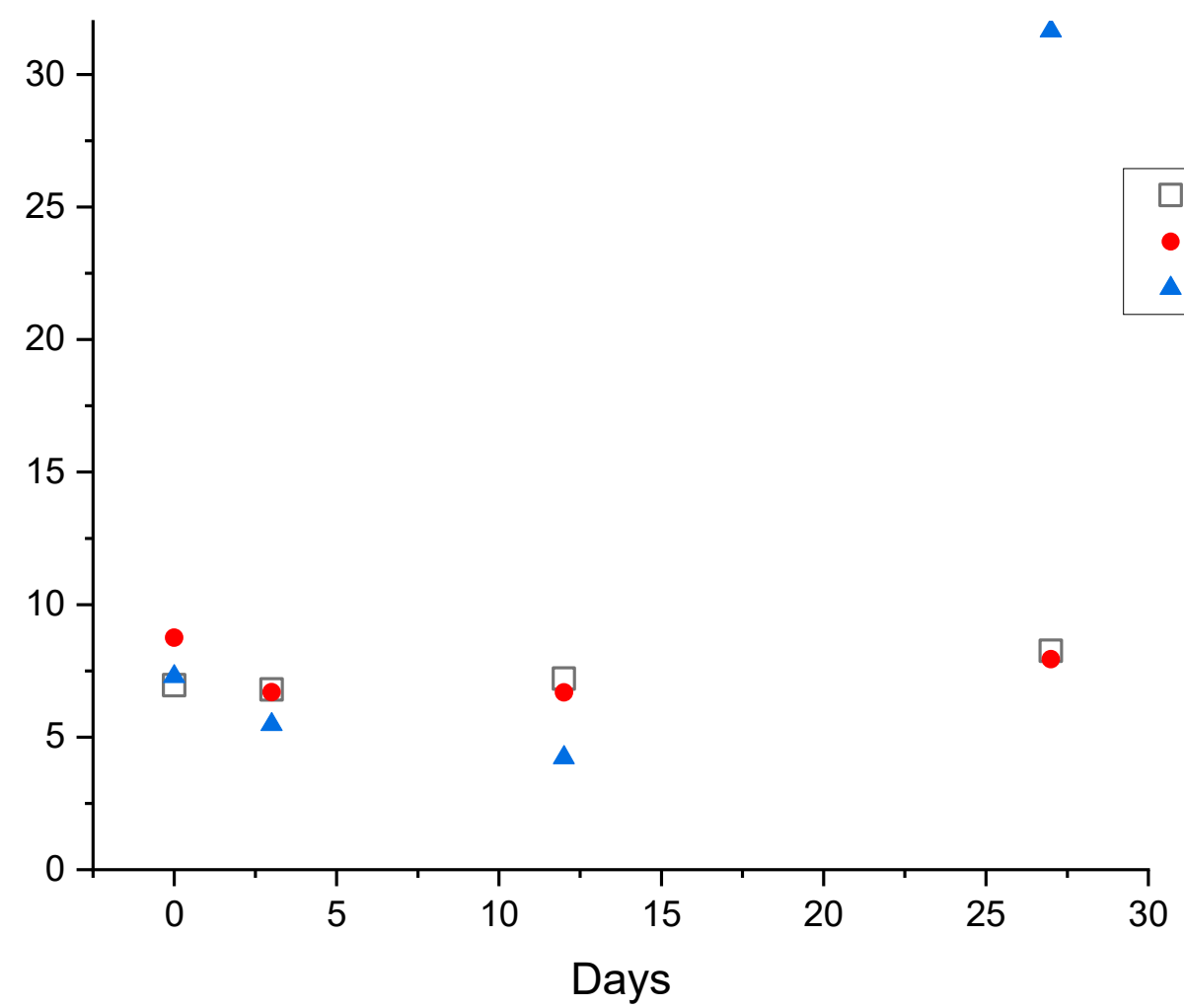

Figure 1. Li capture relative to total biomass in the experimental cultures with additional Li.

According to Jakobsson et al. [27], lithium uptake may be explained by its competition with sodium, using the same entrance mechanisms; most of its biological effects can be attributed to competition with $\mathrm{Na}, \mathrm{Mg}$, and $\mathrm{K}$ sites. $\mathrm{Na}$ and $\mathrm{Li}$ ions have similar properties such as small size, the same acid-base behaviour, and the same number of electrons in the last electron shell [67], which accounts for their similar behaviour in biological systems. High salt concentrations may result in being toxic to microalgae, so the species thriving in saline environments may keep sodium ions away from the cells relying on active transport or may conceal the ions in vacuoles far from metabolic processes as well [68]. $\mathrm{Li}^{+}$ions in cells could follow a similar path. A recent study also showed that in Chlorella vulgaris, the $\mathrm{K}^{+}$concentration affected Li uptake [54]. In this latter study, Li biosorption was observed 
followed by desorption in the following days as well as a trend where a decrease in the $\mathrm{K}^{+}$medium concentration increased the Li uptake in a media where $\mathrm{Rb}^{+}$was also present. The total Li uptake when $\mathrm{K}^{+}$concentration was reduced to $60 \%$ was $4.70 \mathrm{mg} / \mathrm{g}$ dry mass, a 4.48-fold increase compared to the medium with non-altered $\mathrm{K}^{+}$concentration. This observation, if further studies are conducted, could lead towards the design of culture media for biotechnological Li capture purposes. Furthermore, this observation extends the idea of the Li behaviour in microbial systems as an incidental substitute for biological ions, such as $\mathrm{K}^{+}$, in microalgae.

\subsection{Fractionation}

Since biological isotopic fractionation is a relatively frequent natural process [40], we aimed to obtain lithium isotopic fractionation by taking advantage of microalgae properties. Lithium isotopic fractionation based on the activity of bacteria was already published by Sakaguchi and Tomita (2000) [41], where a maximum $\delta^{6}$ of $58.7 \%$ o was obtained using the bacteria Bacillus megaterium. However, from that point on, little effort and resources have been dedicated to advancing the field of microbial lithium fractionation, as we have not encountered any other publications respecting this topic, particularly in terms of microalgal lithium fractionation. Furthermore, until recently, neither the growth of plants [69] nor phytoplankton [70] had shown a significant Li fractionation ability in naturally occurring lithium concentrations. Nevertheless, a recent study revealed that plants are indeed capable of fractioning ${ }^{6} \mathrm{Li}$ with, e.g., an observed $\delta^{7}$ of $12.2 \%$ in rhizomes from a humid region, whereas the $\delta^{7}$ observed in the grass blades was 6.2\%o [71]. In our study we extended this knowledge, confirming that, under laboratory conditions, some microalgae, or, more precisely, our three strains belonging to the phylum Chlorophyta, can differentiate between lithium isotopes. On the contrary, one study conducted in the Laxa river in Iceland pinpointed that microalgae did not affect Li fractionation in this natural environment [70]. Many different variables could affect the different observed outcomes such as natural and laboratory conditions, Li concentration, algae species, biomass, or geochemical processes that may be involved in natural environments.

Our three strains showed diverse behaviours in Li fractionation, with a preference for ${ }^{6} \mathrm{Li}$, as shown in Figure 2a-c. As stated by Balter and Vigier (2014) [22], ${ }^{6} \mathrm{Li}$ has a more relevant role in biological systems than ${ }^{7} \mathrm{Li}$ due to the greater diffusion rate of ${ }^{6} \mathrm{Li}$ resulting from the difference in relative mass. Thus, a kinetic isotope effect during $\mathrm{Li}$ uptake by our microalgae could explain their preference towards the lighter Li isotope. However, our study does not delve deep into the reasons for Li fractionation, so we cannot ascertain that the kinetic isotope effect is the only process taking place. Opposite results should not be considered abnormal, as algae have previously shown a preference for ${ }^{41} \mathrm{~K}$ [72] - the heavier stable $\mathrm{K}$ isotope-with $\mathrm{K}$ being an element biologically related to Li. Additionally, studies in the different animal cells in mammals evidenced that Li isotopic fractionation varies depending on which organ each cell type belongs to [22]. Some speciesspecific characteristics are required to fully explain the different behaviours that have been observed, such as the composition of the cell wall, which is species-dependent [73], or the presence of transporters with isotopic differentiation capacity both for influx and efflux from cells. More research is required in this field to understand the reasons hidden behind this phenomenon and to expand the knowledge of each cell physiology and thus to predict possible fractionation outcomes. 


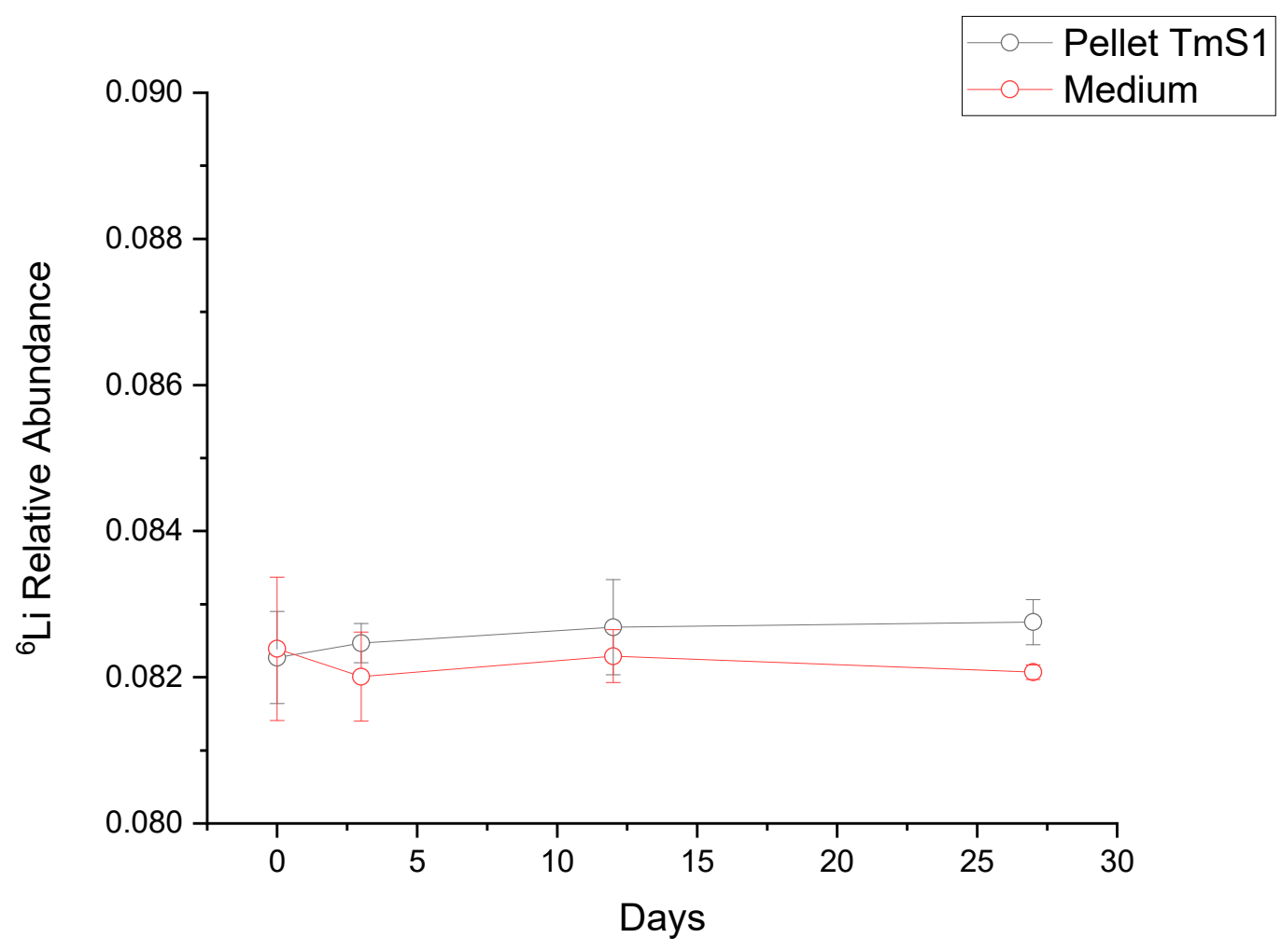

(a)

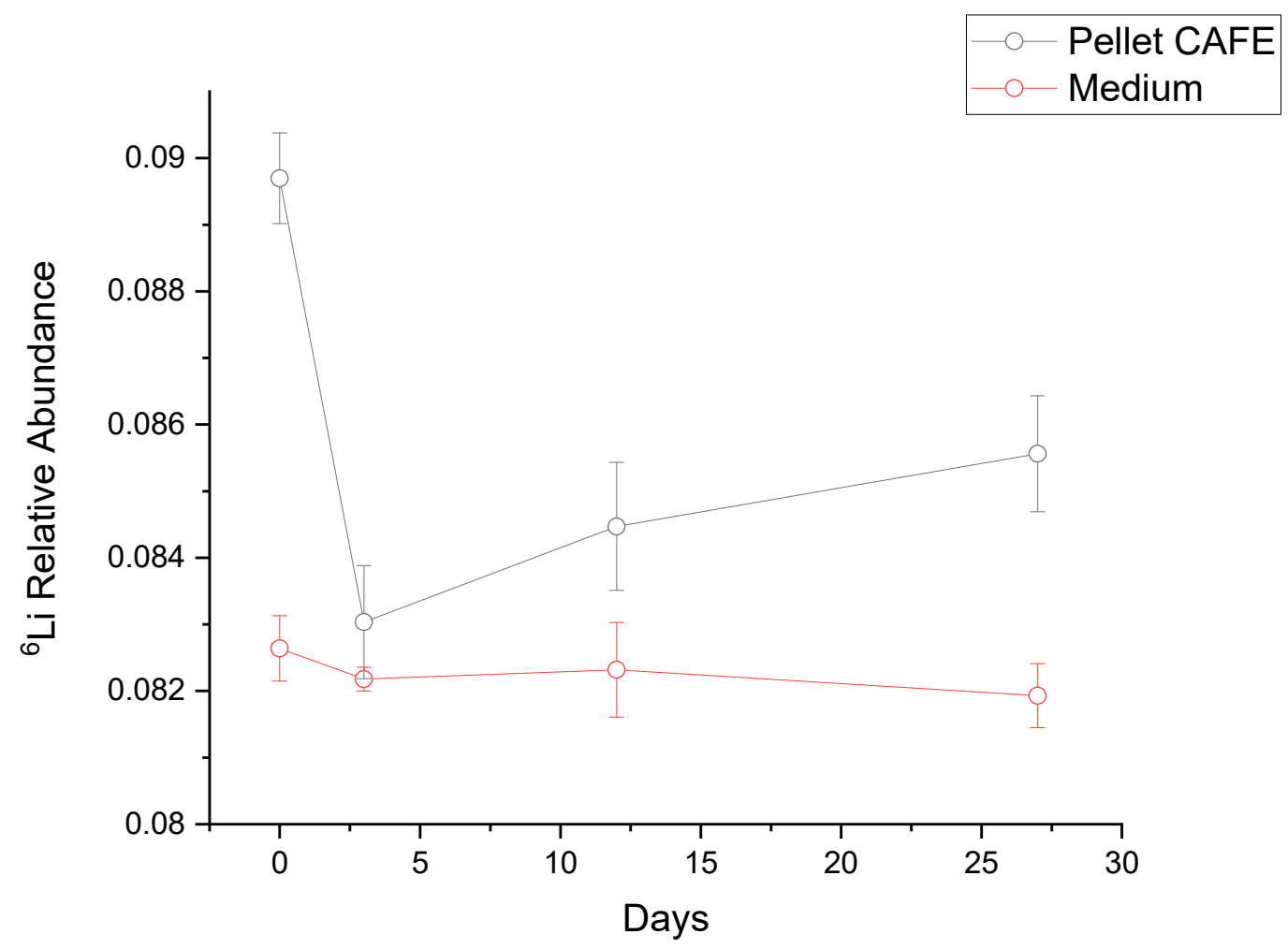

(b)

Figure 2. Cont. 


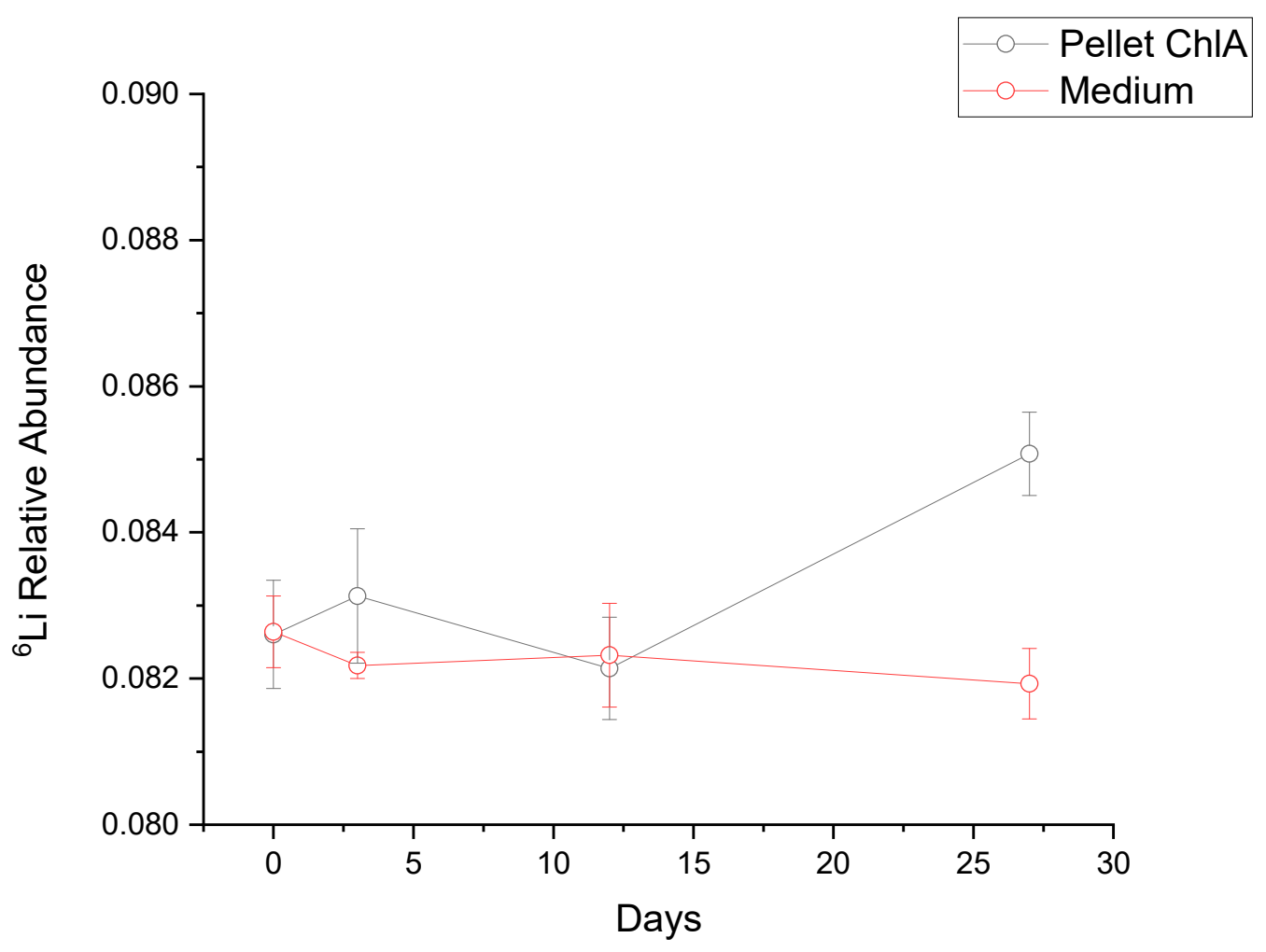

(c)

Figure 2. Isotopic relations for ${ }^{6} \mathrm{Li}$ analysed in the trials with strains (a) TmS1, (b) CAFE, and (c) ChlA, and the observed fractionation on days $0,3,12$, and 27 , respectively. Black circles correspond to the pellet's isotopic relation, while red circles correspond to the media.

\subsection{Biotechnological Perspectives}

The experimental species were not selected, nor were they in previous contact with high Li concentrations. The two freshwater strains, ChlA and CAFE, were isolated from pristine environments where only trace Li levels are expected. TmS1 was isolated from the Mediterranean Sea, where Li concentrations around $200 \mu \mathrm{g} / \mathrm{L}$ are found [74], which are well below our experimental levels. Despite this, Li was captured and isotopically fractionated.

An artificial selection process could be conducted to obtain more efficient Li-capturing strains, which, in turn, could amplify—or not—-the $\delta^{6}$. For instance, microalgae have been previously selected with the purpose of improving uranium uptake [64]. In our case, an artificial selection towards the obtainment of microalgae strains capable of greater Li capture could be achieved by selecting high-salinity resistant species that avoid the toxic effects of the ions by accumulating them in the vacuoles. However, artificial selection towards the obtainment of high-salinity resistant microalgae cells will not always correlate with an increase in ion capture, as some of the mechanisms are directed towards the ion efflux [68]. Another way to obtain microalgae with such properties could be through bioprospection in environments with high Li concentrations, such as in the Lithium Triangle. In this hypersaline region between Bolivia, Chile, and Argentina, some microalgae species have been detected [75,76]. Recently, a microalga isolated from the Atacama Desert (Chile), part of the Lithium Triangle, has been proposed as a tool for mining waste bioremediation [77]. Extremophile and extremotolerant species living there may possess mechanisms that could lead to increased capture or fractionation. Nevertheless, it must be stated that an almost perfect capture would not be desirable for fractionation purposes as the $\delta^{6}$ would be close to $0 \%$. 
The fractionation outcomes, as long as the enrichment factor is high enough, would always be beneficial for biotechnological enrichment purposes, whether the microorganisms favour the lighter or heavier isotope. Given that the aim of the present research was to obtain ${ }^{6} \mathrm{Li}$, our three species provided this possibility. ${ }^{6} \mathrm{Li}$ is concentrated in the cellular pellet, so with the removal of the microalgae, we would obtain ${ }^{6} \mathrm{Li}$-enriched lithium. With our CAFE strain, a $\delta^{6}$ of $85.4 \%$ was obtained moments after inoculation, which also had the maximum relative Li capture $(8.76 \mu \mathrm{g}$ per $\mathrm{g}$ of biomass), so this strain biomass could prove to be suitable as an enrichment tool. ChlA also showed a high $\delta^{6}$ of $38.4 \%$ at day 27, with an even greater Li relative capture than CAFE (31.66 $\mu$ g per $g$ of biomass). Complementarily, the liquid media would be enriched in ${ }^{7} \mathrm{Li}$. On the contrary, if the species took up ${ }^{7} \mathrm{Li}$ preferentially, it would be the liquid matrix the one enriched in ${ }^{6} \mathrm{Li}$, whereas the pellet would contain concentrated ${ }^{7} \mathrm{Li}$.

For industrial up-scale, more species and times as well as other parameters such as light intensity, Li concentration, or culture media composition could be screened to reach optimal capture and fractionation.

\section{Conclusions}

Microalgae have the potential to become useful for Li enrichment. Though no great capture was achieved during this assay, the vast number of microalgae species and ample environmental conditions for the biotechnological process ensure that an optimal capture will eventually be detected. Additionally, if the Li pathways in microalgae are more widely studied, other approaches such as genetic engineering may be used for the obtainment of high-capturing high-fractionating microalgae strains. Nevertheless, as the Li capture approaches $100 \%$, logically, the Li enrichment nears $\delta^{6}=0 \%$, so a complete Li removal would not be desired for fractionation purposes.

In our assay, the maximum $\delta^{6}$ was observed with CAFE, a randomly chosen strain, thus pointing to the importance of extensive trials to detect biotechnologically valuable species.

In conclusion, even if knowledge is still limited, our results demonstrate that microalgae are capable of capturing $\mathrm{Li}$ and, in doing so, fractionate $\mathrm{Li}$ isotopes. Advances in this field might lead the way towards future nuclear biotechnology that will be able to fuel a future mix of electric generation with reliable nuclear (fission or/and fusion) reactors and variable renewables as a perfect combination of $\mathrm{CO}^{2}$ free emissions sources combined with advanced batteries for electric transportation that are urgently needed to fight climate change. The development of these technologies will require the massive use of Li isotopes, and Gaia could give us the cleanest and more sustainable tool for this fractionation.

Author Contributions: Conceptualization, H.M.D.-A., V.L.-R., C.G.-B., F.T. and E.C. (Eduardo Costas); formal analysis, A.I.B. and E.C. (Estefanía Conde); investigation, H.M.D.-A., V.L.-R. and C.G.-B.; methodology, V.L.-R., C.G.-B., A.I.B. and E.C. (Estefanía Conde); writing-original draft, H.M.D.-A., C.G.-B., A.I.B. and E.C. (Estefanía Conde); writing-review and editing, V.L.-R., F.T. and E.C. (Eduardo Costas). All authors have read and agreed to the published version of the manuscript.

Funding: This work was supported by the Fondo Específico de Investigación (FEI-UCM), Fundación General, Universidad Complutense, Madrid (Spain).

Institutional Review Board Statement: Not applicable.

Informed Consent Statement: Not applicable.

Acknowledgments: Special thanks to Paloma Martínez-Alesón for her technical support and to Beatriz Baselga-Cervera, University of Minnesota, for commentary on the manuscript. Thanks are also given to Secugen S.L. for the $18 \mathrm{~S}$ and ITS gene sequencing.

Conflicts of Interest: The authors declare no conflict of interest. 


\section{References}

1. International Energy Agency. World Energy Outlook 2020; International Energy Agency: Paris, France, 2020.

2. Ongena, J.; Van Oost, G. Energy for future centuries: Prospects for fusion power as a future energy source. Fusion Sci. Tech. 2012, 61, 3-16. [CrossRef]

3. ITER-The Way to New Energy. Available online: https://www.iter.org/ (accessed on 3 March 2020).

4. Meija, J.; Coplen, T.B.; Berglund, M.; Brand, W.A.; De Bièvre, P.; Gröning, M.; Holden, N.E.; Irrgeher, J.; Loss, R.D.; Walczyk, T.; et al. Isotopic compositions of the elements 2013 (IUPAC Technical Report). Pure Appl. Chem. 2016, 88, 293-306. [CrossRef]

5. Bradshaw, A.M.; Hamacher, T.; Fischer, U. Is nuclear fusion a sustainable energy form? Fusion Eng. Des. 2010, 86, 2770. [CrossRef]

6. Nishio, S.; Ohmori, J.; Kuroda, T.; Tobita, K.; Enoeda, M.; Tsuru, D.; Hirose, S.; Sato, Y.; Kawamura, H.; Nakamura, M.; et al. Consideration on blanket structure for fusion DEMO plant at JAERI. Fusion Eng. Des. 2006, 81, 1271-1276. [CrossRef]

7. Tobita, K.; Nishio, S.; Tanigawa, H.; Enoeda, M.; Isono, T.; Nakamura, H.; Tsuru, D.; Suzuki, S.; Hayashi, T.; Tsuchiya, K.; et al. Torus configuration and materials selection on a fusion DEMO reactor, SlimCS. J. Nucl. Mater. 2009, 386-388, 888-892. [CrossRef]

8. Herranz García, J.L. Viabilidad Técnica para la Explotación y Separación Isotópica de Li y Prospectiva en el Mercado de Baterías de ION-7Li y de 6 Li como Material Base de Diseño en Reactores de Fusión Nuclear; E.T.S.I. Minas (UPM): Madrid, Spain, 2013.

9. Giegerich, T.; Battes, K.; Schwenzer, J.C.; Day, C. Development of a viable route for lithium-6 supply of DEMO and future fusion power plants. Fusion Eng. Des. 2019, 149, 111339. [CrossRef]

10. Cui, L.; Yang, X.; Wang, J.; He, H.; Guo, Y.; Cheng, F.; Zhang, S. Theoretical prediction of 6 Li / 7 Li separation in solvent extraction system using Urey model. Chem. Eng. J. 2019, 358, 435-445. [CrossRef]

11. Brooks, S.C.; Southworth, G.R. History of mercury use and environmental contamination at the Oak Ridge Y-12 Plant. Environ. Pollut. 2011, 159, 219-228. [CrossRef]

12. Zhang, P.; Wang, M.; Sun, J.; Shao, F.; Jia, Y.; Jing, Y. Lithium Isotope Green Separation Using Water Scrubbing. Chem. Lett. 2019, 48, 1541-1543. [CrossRef]

13. Burton, K.W.; Vigier, N. Lithium Isotopes as Tracers in Marine and Terrestrial Environments. In Handbook of Environmental Isotope Geochemistry. Advances in Isotope Geochemistry; Springer: Berlin/Heidelberg, Germany, 2012; pp. 41-59. [CrossRef]

14. Taylor, T.I.; Urey, H.C. Fractionation of the Lithium and Potassium Isotopes by Chemical Exchange with Zeolites. J. Chem. Phys. 1938, 6, 429. [CrossRef]

15. Pistiner, J.S.; Henderson, G.M. Lithium-isotope fractionation during continental weathering processes. Earth Planet. Sci. Lett. 2003, 214, 327-339. [CrossRef]

16. Huh, Y.; Chan, L.H.; Edmond, J.M. Lithium isotopes as a probe of weathering processes: Orinoco River. Earth Planet. Sci. Lett. 2001, 194, 189-199. [CrossRef]

17. Vigier, N.; Gislason, S.R.; Burton, K.W.; Millot, R.; Mokadem, F. The relationship between riverine lithium isotope composition and silicate weathering rates in Iceland. Earth Planet. Sci. Lett. 2009, 287, 434-441. [CrossRef]

18. Pogge von Strandmann, P.A.E.; Kasemann, S.A.; Wimpenny, J.B. Lithium and Lithium Isotopes in Earth's Surface Cycles. Elements 2020, 16, 253-258. [CrossRef]

19. Hoefs, J.; Sywall, M. Lithium isotope composition of Quaternary and Tertiary biogene carbonates and a global lithium isotope balance. Geochim. Cosmochim. Acta 1997, 61, 2679-2690. [CrossRef]

20. Rudnick, R.L.; Tomascak, P.B.; Njo, H.B.; Gardner, L.R. Extreme lithium isotopic fractionation during continental weathering revealed in saprolites from South Carolina. Chem. Geol. 2004, 212, 45-57. [CrossRef]

21. Rudnick, R.L.; Nakamura, E. Preface to "Lithium isotope geochemistry". Chem. Geol. 2004, 212, 1-4. [CrossRef]

22. Balter, V.; Vigier, N. Natural variations of lithium isotopes in a mammalian model. Metallomics 2014, 6, 582-586. [CrossRef]

23. Sherman, W.R.; Munsell, L.Y.; Wong, Y.-H.H. Differential Uptake of Lithium Isotopes by Rat Cerebral Cortex and Its Effect on Inositol Phosphate Metabolism. J. Neurochem. 1984, 42, 880-882. [CrossRef]

24. Lieberman, K.; Alexander, G.J.; Sechzer, J.A. Stable isotopes of lithium: Dissimilar biochemical and behavioral effects. Experientia 1986, 42, 985-987. [CrossRef]

25. Stoll, P.M.; Stokes, P.E.; Okamoto, M. Lithium isotopes: Differential effects on renal function and histology. Bipolar Disord. 2001, 3, 174-180. [CrossRef]

26. Lieberman, K.W.; Alexander, G.J.; Stokes, P. Dissimilar effects of lithium isotopes on motility in rats. Pharmacol. Biochem. Behav. 1979, 10, 933-935. [CrossRef]

27. Jakobsson, E.; Argüello-Miranda, O.; Chiu, S.W.; Fazal, Z.; Kruczek, J.; Nunez-Corrales, S.; Pandit, S.; Pritchet, L. Towards a Unified Understanding of Lithium Action in Basic Biology and its Significance for Applied Biology. J. Membr. Biol. 2017, 250, 587-604. [CrossRef] [PubMed]

28. Shahzad, B.; Mughal, M.N.; Tanveer, M.; Gupta, D.; Abbas, G. Is lithium biologically an important or toxic element to living organisms? An overview. Environ. Sci. Pollut. Res. 2017, 24, 103-115. [CrossRef]

29. Dolara, P. Occurrence, exposure, effects, recommended intake and possible dietary use of selected trace compounds (aluminium, bismuth, cobalt, gold, lithium, nickel, silver). Int. J. Food Sci. Nutr. 2014, 65, 911-924. [CrossRef] [PubMed]

30. Tanveer, M.; Hasanuzzaman, M.; Wang, L. Lithium in Environment and Potential Targets to Reduce Lithium Toxicity in Plants. J. Plant. Growth Regul. 2019, 38, 1574-1586. [CrossRef]

31. Shahzad, B.; Tanveer, M.; Hassan, W.; Shah, A.N.; Anjum, S.A.; Cheema, S.A.; Ali, I. Lithium toxicity in plants: Reasons, mechanisms and remediation possibilities-A review. Plant Physiol. Biochem. 2016, 107, 104-115. [CrossRef] 
32. Lopilato, J.; Tsuchiya, T.; Wilson, T.H. Role of $\mathrm{Na}+$ and $\mathrm{Li}+$ in thiomethylgalactoside transport by the melibiose transport system of Escherichia coli. J. Bacteriol. 1978, 134, 147-156. [CrossRef]

33. Kayama-Gonda, Y.; Kawasaki, T. Role of lithium ions in proline transport in Escherichia coli. J. Bacteriol. 1979, 139, 560-564. [CrossRef]

34. Granger, J.; Sigman, D.M.; Lehmann, M.F.; Tortell, P.D. Nitrogen and oxygen isotope fractionation during dissimilatory nitrate reduction by denitrifying bacteria. Limnol. Oceanogr. 2008, 53, 2533-2545. [CrossRef]

35. Kritee, K.; Blum, J.D.; Johnson, M.W.; Bergquist, B.A.; Barkay, T. Mercury stable isotope fractionation during reduction of Hg(II) to $\mathrm{Hg}(0)$ by Mercury resistant microorganisms. Environ. Sci. Technol. 2007, 41, 1889-1895. [CrossRef]

36. Macko, S.A.; Fogel, M.L.; Hare, P.E.; Hoering, T.C. Isotopic fractionation of nitrogen and carbon in the synthesis of amino acids by microorganisms. Chem. Geol. Isot. Geosci. Sect. 1987, 65, 79-92. [CrossRef]

37. Penger, J.; Conrad, R.; Blaser, M. Stable carbon isotope fractionation of six strongly fractionating microorganisms is not affected by growth temperature under laboratory conditions. Geochim. Cosmochim. Acta 2014, 140, 95-105. [CrossRef]

38. Chambers, L.A.; Trudinger, P.A. Microbiological fractionation of stable sulfur isotopes: A review and critique. Geomicrobiol. J. 1979, 1, 249-293. [CrossRef]

39. Pokrovsky, O.S.; Viers, J.; Emnova, E.E.; Kompantseva, E.I.; Freydier, R. Copper isotope fractionation during its interaction with soil and aquatic microorganisms and metal oxy(hydr)oxides: Possible structural control. Geochim. Cosmochim. Acta 2008, 72, 1742-1757. [CrossRef]

40. Wiederhold, J.G. Metal stable isotope signatures as tracers in environmental geochemistry. Environ. Sci. Technol. 2015, 49, 2606-2624. [CrossRef]

41. Sakaguchi, T.; Tomita, O. Bioseparation of Lithium Isotopes by Using Microorganisms. Resour. Environ. Biotechnol. 2000, 3 , 173-182.

42. García-Balboa, C.; Baselga-Cervera, B.; García-Sanchez, A.; Igual, J.M.; Lopez-Rodas, V.; Costas, E. Rapid adaptation of microalgae to bodies of water with extreme pollution from uranium mining: An explanation of how mesophilic organisms can rapidly colonise extremely toxic environments. Aquat. Toxicol. 2013, 144-145, 116-123. [CrossRef] [PubMed]

43. López-Rodas, V.; Marvá, F.; Rouco, M.; Costas, E.; Flores-Moya, A. Adaptation of the chlorophycean Dictyosphaerium chlorelloides to stressful acidic, mine metal-rich waters as result of pre-selective mutations. Chemosphere 2008, 72, 703-707. [CrossRef]

44. Vadlamani, A.; Viamajala, S.; Pendyala, B.; Varanasi, S. Cultivation of Microalgae at Extreme Alkaline pH Conditions: A Novel Approach for Biofuel Production. ACS Sustain. Chem. Eng. 2017, 5, 7284-7294. [CrossRef]

45. Abinandan, S.; Subashchandrabose, S.R.; Cole, N.; Dharmarajan, R.; Venkateswarlu, K.; Megharaj, M. Sustainable production of biomass and biodiesel by acclimation of non-acidophilic microalgae to acidic conditions. Bioresour. Technol. 2019, 271, 316-324. [CrossRef]

46. Baselga-Cervera, B.; García-Balboa, C.; Díaz-Alejo, H.M.; Costas, E.; López-Rodas, V. Rapid Colonization of Uranium MiningImpacted Waters, the Biodiversity of Successful Lineages of Phytoplankton Extremophiles. Microb. Ecol. 2020, 79, 576-587. [CrossRef]

47. MeGraw, V.E.; Brown, A.R.; Boothman, C.; Goodacre, R.; Morris, K.; Sigee, D.; Anderson, L.; Lloyd, J.R. A novel adaptation mechanism underpinning algal colonization of a nuclear fuel storage pond. mBio 2018, 9. [CrossRef] [PubMed]

48. Kottuparambil, S.; Jin, P.; Agusti, S. Adaptation of Red Sea Phytoplankton to Experimental Warming Increases Their Tolerance to Toxic Metal Exposure. Front. Environ. Sci. 2019, 7. [CrossRef]

49. Sánchez-Alvarez, E.L.; González-Ledezma, G.; Bolaños Prats, J.A.; Stephano-Hornedo, J.L.; Hildebrand, M. Evaluating Marinichlorella kaistiae KAS603 cell size variation, growth and TAG accumulation resulting from rapid adaptation to highly diverse trophic and salinity cultivation regimes. Algal Res. 2017, 25, 12-24. [CrossRef]

50. Suresh Kumar, K.; Dahms, H.U.; Won, E.J.; Lee, J.S.; Shin, K.H. Microalgae- A promising tool for heavy metal remediation. Ecotoxicol. Environ. Saf. 2015, 113, 329-352. [CrossRef] [PubMed]

51. Mehta, S.K.; Gaur, J.P. Use of Algae for Removing Heavy Metal Ions From Wastewater: Progress and Prospects. Crit. Rev. Biotechnol. 2005, 25, 113-152. [CrossRef]

52. Monteiro, C.M.; Castro, P.M.L.; Malcata, F.X. Metal uptake by microalgae: Underlying mechanisms and practical applications. Biotechnol. Prog. 2012, 28, 299-311. [CrossRef]

53. Sandau, E.; Sandau, P.; Pulz, O. Heavy metal sorption by microalgae. Acta Biotechnol. 1996, 16, 227-235. [CrossRef]

54. Kaštánek, P.; Kronusová, O.; Kaštánek, F.; Brányiková, I.; Prochazková, G.; Jandová, J.; Brányik, T.; Bišová, K. Selective bioaccumulation of rubidium by microalgae from industrial wastewater containing rubidium and lithium. J. Appl. Phycol. 2018, 30, 461-467. [CrossRef]

55. Levy, J.L.; Angel, B.M.; Stauber, J.L.; Poon, W.L.; Simpson, S.L.; Cheng, S.H.; Jolley, D.F. Uptake and internalisation of copper by three marine microalgae: Comparison of copper-sensitive and copper-tolerant species. Aquat. Toxicol. 2008, 89, 82-93. [CrossRef]

56. Saavedra, R.; Muñoz, R.; Taboada, M.E.; Vega, M.; Bolado, S. Comparative uptake study of arsenic, boron, copper, manganese and zinc from water by different green microalgae. Bioresour. Technol. 2018, 263, 49-57. [CrossRef] [PubMed]

57. Terry, P.A.; Stone, W. Biosorption of cadmium and copper contaminated water by Scenedesmus abundans. Chemosphere 2002, 47 , 249-255. [CrossRef]

58. Baselga-Cervera, B.; García-Balboa, C.; López-Rodas, V.; Fernández Díaz, M.; Costas, E. Evidence of microalgal isotopic fractionation through enrichment of depleted uranium. Sci. Rep. 2019, 9, 1973. [CrossRef] [PubMed] 
59. El-Naggar, N.E.A.; Hamouda, R.A.; Rabei, N.H.; Mousa, I.E.; Abdel-Hamid, M.S. Phycoremediation of lithium ions from aqueous solutions using free and immobilized freshwater green alga Oocystis solitaria: Mathematical modeling for bioprocess optimization. Environ. Sci. Pollut. Res. 2019, 26, 19335-19351. [CrossRef]

60. Scaife, M.A.; Nguyen, G.T.D.T.; Rico, J.; Lambert, D.; Helliwell, K.E.; Smith, A.G. Establishing Chlamydomonas reinhardtii as an industrial biotechnology host. Plant J. 2015, 82, 532-546. [CrossRef] [PubMed]

61. Gutiérrez, C.L.; Muñoz, C.; San Martín, M.; Cadoret, J.P.; Henríquez, V. Chloroplast Dual Divergent Promoter Plasmid for Heterologous Protein Expression in Tetraselmis suecica (Chlorophyceae, Chlorodendrales). J. Phycol. 2020, 56, 1066-1076. [CrossRef]

62. Wang, Y.; Tian, R.M.; Gao, Z.M.; Bougouffa, S.; Qian, P.-Y. Optimal Eukaryotic $18 \mathrm{~S}$ and Universal 16S/18S Ribosomal RNA Primers and Their Application in a Study of Symbiosis. PLoS ONE 2014, 9, e90053. [CrossRef]

63. Cheng, T.; Xu, C.; Lei, L.; Li, C.; Zhang, Y.; Zhou, S. Barcoding the kingdom Plantae: New PCR primers for ITS regions of plants with improved universality and specificity. Mol. Ecol. Resour. 2016, 16, 138-149. [CrossRef] [PubMed]

64. Baselga-Cervera, B.; Romero-López, J.; García-Balboa, C.; Costas, E.; López-Rodas, V. Improvement of the uranium sequestration ability of a Chlamydomonas sp. (ChlSP strain) isolated from extreme uranium mine tailings through selection for potential bioremediation application. Front. Microbiol. 2018, 9, 523. [CrossRef]

65. Zhao, Z.; Rasool, M.A.; Chen, C.; Ma, S.; Wang, L.; Huang, G. Identification and screening of multiple tropical microalgal strains for antioxidant activity in vitro. Food Biosci. 2020, 36, 100649. [CrossRef]

66. Jeong, D.; Jang, A. Exploration of microalgal species for simultaneous wastewater treatment and biofuel production. Environ. Res. 2020, 188, 109772. [CrossRef]

67. Litio y Sodio-Propiedades. Available online: https://elementos.org.es/litio-y-sodio (accessed on 20 January 2021).

68. Hagemann, M. Coping with High and Variable Salinity: Molecular Aspects of Compatible Solute Accumulation. In The Physiology of Microalgae; Borowitzka, M.A., Beardall, J., Raven, J.A., Eds.; Springer International Publishing: Berlin/Heidelberg, Germany, 2016; pp. 359-372. [CrossRef]

69. Clergue, C.; Dellinger, M.; Buss, H.L.; Gaillardet, J.; Benedetti, M.F.; Dessert, C. Influence of atmospheric deposits and secondary minerals on Li isotopes budget in a highly weathered catchment, Guadeloupe (Lesser Antilles). Chem. Geol. 2015, 414, 28-41. [CrossRef]

70. Pogge von Strandmann, P.A.E.; Burton, K.W.; Opfergelt, S.; Eiríksdóttir, E.S.; Murphy, M.J.; Einarsson, A.; Gislason, S. The effect of hydrothermal spring weathering processes and primary productivity on lithium isotopes: Lake Myvatn, Iceland. Chem. Geol. 2016, 445, 4-13. [CrossRef]

71. Li, W.; Liu, X.M.; Chadwick, O.A. Lithium isotope behavior in Hawaiian regoliths: Soil-atmosphere-biosphere exchanges. Geochim. Cosmochim. Acta 2020, 285, 175-192. [CrossRef]

72. Li, W. Vital effects of $\mathrm{K}$ isotope fractionation in organisms: Observations and a hypothesis. Acta Geochim. 2017, 36, 374-378. [CrossRef]

73. Alhattab, M.; Kermanshahi-Pour, A.; Brooks, M.S.L. Microalgae disruption techniques for product recovery: Influence of cell wall composition. J. Appl. Phycol. 2019, 31, 61-88. [CrossRef]

74. Morozov, N.P. (Table 2d) Lithium and rubidium concentrations in waters of the Mediterranean Sea. PANGAEA 1968. [CrossRef]

75. Hayashida, G.; Schneider, C.; Espíndola, L.; Arias, D.; Riquelme, C.; Wulff-Zottele, C.; Díaz-Palma, P.; Rivas, M. Characterization of a Chlorophyta microalga isolated from a microbial mat in Salar de Atacama (northern Chile) as a potential source of compounds for biotechnological applications. Phycol. Res. 2017, 65, 202-211. [CrossRef]

76. Hernández, K.L.; Yannicelli, B.; Olsen, L.M.; Dorador, C.; Menschel, E.J.; Molina, V.; Remonsellez, F.; Hengst, M.B.; Jeffrey, W.H. Microbial Activity Response to Solar Radiation across Contrasting Environmental Conditions in Salar de Huasco, Northern Chilean Altiplano. Front. Microbiol. 2016, 7, 1857. [CrossRef]

77. Martínez, M.; Leyton, Y.; Cisternas, L.; Riquelme, C. Metal Removal from Acid Waters by an Endemic Microalga from the Atacama Desert for Water Recovery. Minerals 2018, 8, 378. [CrossRef] 